\title{
The moderating role of gender on entrepreneurial intentions: A TPB perspective
}

\author{
José Luis Ruizalba Robledo, María Vallespín Arán², \\ Victor Martin-Sanchez ${ }^{3}$, Miguel Ángel Rodríguez Molina ${ }^{4}$ \\ ${ }^{1}$ The Claude Littner Business School. University of West London (United Kingdom) \\ ${ }^{2}$ Universidad de Málaga, ${ }^{3}$ Universitat Autònoma de Barcelona, ${ }^{4}$ Universidad de Granada (Spain) \\ jose.ruizalba@uwl.ac.uk,.mvallespin@uma.es, victor.martin.sanchez@uab.cat,rmolina@ugr.es
}

\section{Abstract}

Purpose: To disentangle the ways in which social norms shape entrepreneurial intentions of university students and to analyse the moderating effect of gender that may arise.

Design/methodology/approach: We have used the entrepreneurial intention model based on Theory of Planned Behaviour (TPB) literature and moderated by students' gender affecting this intention. We tested some hypotheses using data from undergraduate business students in Spain and their entrepreneurial intentions.

Findings: Our results suggest that perceived behavioural control and attitudes affect the entrepreneurial intentions of university students towards entrepreneurship while subjective norms do not. Furthermore, our findings reveal that the moderating effect of gender has a positive influence for women in the relationship between those subjective norms and the perceived behavioural control. However, as to some research done so far, the moderating role of gender does not seem to have a particular effect on predicting entrepreneurial intentions when moderating TPB dimensions. 
Practical implications: Given the socio-economic benefits attributed to entrepreneurship, the results allow the design of more effective education initiatives and policies.

Originality/value: This research provides support for the application of the TPB, allowing for a better understanding of gender differences in entrepreneurial intentions.

Keywords: Entrepreneurial intentions, Theory of Planned Behaviour, University students, Gender, Subjective norm, Perceived behavioural control

Jel Codes: L26, M13, I23, I28, O15

\section{Introduction}

According to Krueger and Brazeal (1994), the entrepreneurship process is subject to entrepreneurial potential and potential entrepreneurs from either individuals or organizations when directed towards innovation. In this sense, we consider the study of entrepreneurial intentions and its understanding to be very important nowadays. Entrepreneurial intentions is a topic widely discussed by many researchers over the last decades (e.g. Krueger \& Carsrud, 1993; Liñán \& Chen, 2009). Specifically, a branch of literature on entrepreneurial intentions is focusing attention on entrepreneurial universities' and university students' study of entrepreneurship (Kirby, Guerrero \& Urbano, 2011; Liñán, Urbano \& Guerrero, 2011; Veciana, Aponte \& Urbano, 2005). This is why women university students may be considered potential entrepreneurs with opportunity perception and start-up motivations and why the study of entrepreneurial intentions within this group merits our attention.

In this article, we aim to disentangle the ways in which social norms shape entrepreneurial intentions of university students and to analyse the moderating effect of gender that may arise. In this sense, the gender factor has also been studied from the social-cognitive perspective when measuring the antecedent factors of determining entrepreneurial intentions (Zhao, Hills \& Siebert, 2005). Hence, the reason we study entrepreneurial intentions is because prior research has argued that it may be a main driver in understanding the new-firm creation process (Bird, 1988; Liñán \& Chen, 2009; Liñán et al., 2011).

As an answer to the claim from Mitchell, Busenitz, Bird, Gaglio, Mcmullen and Morse (2007) suggesting that the future of entrepreneurship research should deal with the social cognitive categories (Liñán et al., 2011), we consider the analysis of business university students' entrepreneurial intentions very important. We approach this issue considering the Theory of Planned Behaviour, which will allow us to understand those personal and behavioural 
characteristics such as attitudes, perceptions and subjective norms. Besides, we consider of great importance adding the moderator effect of gender (Delmar \& Davidsson, 2000; Veciana et al., 2005) because the literature still lacks a deeper fine-grained analysis of students' gender effect on entrepreneurial intentions looking at the moderator influence.

Several models aim to explain entrepreneurial intentions (such as Shapero's model of entrepreneurial intentions). Some articles have been comparing and discussing both of them (Krueger \& Brazeal, 1994; Veciana et al., 2005). However, even though these models represent a step forward in entrepreneurial behaviour research, they have not been as influential as the Theory of Planned Behaviour (hereinafter, TPB) (Krueger, Reilly \& Carsrud, 2000; Moriano, Gorgievski, Laguna, Stephan \& Zarafshani, 2012; Van Gelderen, Brand, Van Praag, Bodewes, Poutsma \& Van Gils, 2008). According to this perspective, all new venture creation starts using at some point with a certain level of planned behaviour (Krueger et al., 2000; Shook, Priem \& Mcgee, 2003; Thompson, 2009).

Similarly, although intention models represent an important opportunity to increase the ability to understand and predict entrepreneurial activity, individual factors including demographic characteristics or personality traits are believed to play an important role (Uribe, De Pablo \& Bonilla, 2013). Accordingly, some authors have studied the influence of demographic characteristics such as age (Levesque \& Minniti, 2006), education (Autio \& Acs, 2010; Blanchflower \& Oswald, 1998; De Clercq, Honig \& Martin, 2011) and gender (Brush, 1992; Minniti \& Nardone, 2007). On the one hand, Brush's work (1992) reviewed 57 empirical research articles on female business owners. The evidence found was that female business owners did a similar job to males' when considering dimensions like demographic factors, problems, and business characteristics, while they different from each other in individual-level characteristics related to education, work experience, skills, approach to venture creation/acquisition, business goals, problems and performance. On the other hand, Minniti and Nardone (2007) using GEM (Global Entrepreneurship Monitor) data collected in 2002 from 37 countries studied the variables that caused differences in entrepreneurial behaviour across genders and considering the country level effect. The main contribution of their investigation was that perceptual variables played a key role in explaining differences across genders. Nevertheless, still lacking in the literature of TPB is an interplay analysis with individual-level characteristics predicting entrepreneurial intentions. Thus, to disentangle the main drivers of this effect, we aim to analyse the moderator role of gender on TPB and determining those intentions. We think contributing to fill this gap with this paper may bring some new insights of great importance to understand the way TPB is influenced by individual intentions. 
To test our hypotheses we have used the entrepreneurial intentions questionnaire developed by Liñán et al. (2011) corresponding to a modified version by Liñán and Chen (2009) and Guerrero and Urbano (2014). Regarding the methodology, an online questionnaire was sent to late-undergraduate business students in Spain. As Liñán et al. (2011) indicate, recent research has found that young university graduates (25-34 years) show the highest propensity towards starting up a firm (Bosma, Jones, Autio \& Levie, 2008). With a sample of 180 students, we tested our hypotheses using PLS.

The rest of the article is organised as follows. First, we review existing research on the TPB and entrepreneurial intentions moderated by gender and affecting entrepreneurial intentions. Second, we describe the data, variables and methods. Third, we present the results of our empirical analysis reporting the statistical findings and empirical support for hypotheses. Finally, we conclude and discuss the theoretical and practical implications on educators-policy and for decision-makers to foster the cognitive factors affecting students' entrepreneurial intentions.

\section{Theoretical framework and research hypotheses}

\subsection{Entrepreneurial intentions and the Theory of Planned Behaviour (TPB) approach}

Entrepreneurial intentions of individuals are understood today as mainstream in the new business formation literature (Thompson, 2009). Besides, there is evidence that their study represents an important framework for entrepreneurship literature (Carr \& Sequeira, 2007; Hmieleski \& Corbett, 2006; Thompson, 2009; Wilson, Kickul \& Marlino, 2007). In this sense, an individual's entrepreneurial intention reflects his/her level of interest in starting a business (De Clercq et al., 2011; Fitzsimmons \& Douglas, 2011; Krueger et al., 2000; Lent, Brown \& Hackett, 1994) and therefore a subsequent positive influence in employment creation. Additionally, broadly speaking, entrepreneurial intentions seem to be related and linked to the growth literature dash, in particular, to entrepreneurial growth aspirations, which mean how entrepreneurs anticipate the number of jobs they think they will have in the future (Autio \& Acs, 2010; Autio, 2011; Estrin, Korosteleva \& Mickiewicz, 2013; Gartner \& Liao, 2012; Hessels, Van Gelderen \& Thurik, 2008a, 2008b; Tominc \& Rebernik, 2007). Consequently, entrepreneurial intentions are related to behaviour, attitudes, subjective norms and perceived behavioural controls (Ajzen, 1991).

Along these lines, TPB has been widely adopted as one of the most powerful tools to test consumers' behavioural intentions (Ajzen, 2001). Ajzen (2011) provides a generic definition of intention as a person's readiness to perform a given behaviour (Kautonen, Gelderen \& 
Tornikoski, 2013). Ajzen's (1991) TPB model, described how behaviour is formed. According to TPB, one's attitude towards a behaviour, coupled with prevailing subjective norms and with perceptions of behavioural control factors, all serve to influence an individual's intention to perform a given behaviour (Ajzen, 1991). Armitage and Conner (2001) found from a database of 185 independent studies that the TPB accounted for $27 \%$ and $39 \%$ of the variance in behaviour and intention respectively. The TPB framework is based on the individual's intention, which is the result of three determinants: a favourable or unfavourable evaluation of behaviour (attitude), perceived social pressure to perform the behaviour or not (subjective norm), and the perceived ease or difficulty of performing the behaviour (perceived behavioural control, PBC) (Ajzen, 1991).

Much research in the area of entrepreneurship has found empirical support for this theory (Kautonen et al., 2013; Kolvereid, 1996; Krueger et al., 2000; Liñán, 2004; Liñán et al., 2011; Tkachev \& Kolvereid, 1999; Veciana et al., 2005). Based on the planned behaviour approach, it could be argued that individuals take their decision to create a new firm based only on those three motivational factors - attitudes towards behaviour, PBC and subjective norms - that predict behavioural intentions directly (Ajzen, 1991; Liñán, 2004, Liñán et al., 2011). All other factors are theorised to influence intentions through these three components (Moriano et al., 2012). In the entrepreneurial context, the TPB contributes to our understanding of the emergence of entrepreneurial behaviour prior to the onset of any observable action, which has notable implications for policy, for example, if the objective is to promote enterprising activity by fostering a culture conducive to entrepreneurship (Kautonen, Palmroos \& Vainio, 2009; Kautonen et al., 2013; Liñán \& Chen, 2009). In that sense, prior applications of the TPB in the entrepreneurship literature suggest that attitude, subjective norms, and PBC typically explain $30 \%-45 \%$ of the variance in intentions (Kautonen et al., 2013). However, the strength of their influence on intentions varies between studies (Moriano et al., 2012).

In the literature of TPB the dimension of attitude, which is a relatively permanent and stable evaluative summary about an item, is an important psychological construct as it has been found to influence and predict many behaviours (Kraus, 1995). According to the TPB, attitude towards the act refers to the degree to which a person has a favourable or unfavourable evaluation or appraisal of the behaviour in question. In general, the more favourable the attitude towards the behaviour is, the stronger the individual's intention to perform it should be (Ajzen, 1991).

Additionally, perceived behavioural control is defined in the TPB as "people's perception of the ease or difficulty of performing the behaviour of interest" (Ajzen, 1991). Moreover, perceived behavioural control is assumed to reflect past experiences as well as anticipated impediments 
and consequences (Ajzen, 1991). According to TPB, it is the perception of behavioural control as opposed to the degree of actual behavioural control that directly impacts both intentions to perform a behaviour as well as the actual performance of that behaviour. Individuals usually choose to perform behaviours that they think they will be able to control and master.

Finally, in the literature of TPB the dimension of subjective norms has to be with "the perceived social pressure to perform or not to perform the behaviour" by the individual (Ajzen, 1991; Krueger et al., 2000), in other words, the perceived extra personal influences on the decisionmaker (Krueger \& Brazeal, 1994). If an individual perceives that his/her significant others endorse (or disapprove) the behaviour, he/she is more (or less) likely to intend to perform it. In this sense, subjective norms measure the perceived social pressure from family, friends or significant others (Ajzen, 1991). These normative beliefs have to do with the willingness of the motivation towards them (Krueger et al., 2000). Besides, it basically captures two dimensions: normative beliefs and the motivation to comply with these beliefs (Ajzen \& Fishbein, 1980). According to Moriano et al. (2012), in the first case, normative beliefs concern the perceived probability that important referent individuals or groups will approve or reject a given behaviour; they set the norm that specifies how the subject should behave. The second component, motivation to comply, reflects a person's willingness to conform to these norms, that is, to behave in keeping with the expectation of important referents. Depending on the social environment, these pressures can become a trigger or a barrier to the development of an entrepreneurial career. Armitage and Conner (2001) found that the subjective norm construct is generally found to be a weak predictor of intention. In the same way, Liñán and Chen (2009) point out that the traditionally weak role of the subjective norm in the TPB is an important concern within the area of entrepreneurship. However, the results are confusing as, while some studies find a direct relation between subjective norms and entrepreneurial intentions (Díaz-García \& Jiménez-Moreno, 2010), or even that subjective norms have the strongest effect (Kautonen et al., 2013), others do not (Autio, Keeley, Klofsten, Parker \& Hay, 2001; Krueger et al., 2000; Liñán \& Santos, 2007; Liñán et al., 2011). The latter authors expound that the existence of interactions and indirect effects of the subjective norm on intentions could explain these results. While Kautonen et al. (2013) think that this difference in results comes from the fact that the frequent use of student samples as norms set by others may be less relevant for students than for the wider adult population, in Armitage and Conner's (2001) opinion, the explanation could be partly attributable to a combination of poor measurement and the need for expansion of the normative component. In this sense, the possibility of the subjective norm's indirect effects on entrepreneurial intentions should be further investigated as well, as there may be reasons to consider that the subjective norm has an effect on both attitudes and perceived behavioural control (Liñán \& Chen, 2009). 
Therefore, we posit the following hypotheses:

Hypothesis 1: A favourable attitude towards entrepreneurship is positively related to entrepreneurial intentions.

Hypothesis 2: A higher perceived behavioural control is positively related to entrepreneurial intentions.

Hypothesis 3: Supportive subjective norms are positively related to entrepreneurial intentions.

Hypothesis 4: The subjective norm has a positive impact on the attitude towards the behaviour.

Hypothesis 5: The subjective norm has a positive impact on the perceived behavioural control.

\subsection{Students' entrepreneurial intentions: The moderating role of gender}

With the growing interest in entrepreneurship in general, there has been a growing interest in research that has focused on women's entrepreneurship (e.g. Bruni, Gheradi \& Poggio, 2004; Lerner \& Malach-Pines, 2010; Mazzarol, Volery, Doss \& Thein, 1999; Pines, Lerner \& Schwartz, 2010). In fact, there exist several studies that assess that individuals' gender plays a fundamental role in assessing entrepreneurial and self-employment career choice intentions (Verheul, Thurik, Grilo \& Van Der Zwan, 2012). Moreover, it is believed that long term solutions to reduce gender differential in entrepreneurship have to begin in the educational system and, therefore, it is important to find out the aspects related to gender that have to be treated carefully in the educational and formative programs (Díaz-García \& Jiménez-Moreno, 2010).

There are reasons that make studying the role of gender in the entrepreneurship area interesting. From a demographic perspective it is well known that there exist differences and analyses across gender and entrepreneurial behaviour as well as attitudes towards new venture creation (Delmar \& Davidsson, 2000; Kolvereid, 1996; Kourilsky \& Walstad, 1998; Matthews \& Moser, 1995; Scherer, Adams, Carley \& Wiebe, 1989; Veciana et al., 2005). In line with our empirical methodological approach, other investigations have used the same quantitative perspective and the effect of gender to study the particular case of female university students' intentions towards entrepreneurship. In this way, gender has been paid attention to in others' TPB work approach (e.g. Díaz-García \& Jiménez-Moreno, 2010; Maes, Leroy \& Sels, 2014; Verheul et al., 2012). 
Some studies that have already analysed this impact show that males have a larger preference for entrepreneurship behaviour than females (Delmar \& Davidsson, 2000; Matthews \& Moser, 1995; Rodríguez \& Santos, 2008; Scherer et al., 1989; Ventura \& Quero, 2013). Kolvereid (1996), in his application of the TPB to predict employment status choice, concluded that gender influences self-employment intentions indirectly through their effect on attitude, subjective norm, and perceived behavioural control.

The attitude towards entrepreneurial behaviour is the student's affective evaluation of the cost and benefits of starting a business, and women tend to be driven by different job values and work motivations than men (Verheul et al., 2012). Kirk and Belovics's work (2006) summarises that women choose entrepreneurship to balance work and family, whereas men seek wealth creation. In another way, in their review of the literature, Brenner, Pringle and Greenhaus (1991) argue that women value work that helps them to develop their knowledge and skills, that is intellectually stimulating, and that has agreeable working conditions, while men prefer high incomes, taking risks and supervising others (Verheul et al., 2012).

On the other hand, and with regard to subjective norms, as Shane (1992) indicates, norms can frequently reflect the influence of social values and attitudes, and have been identified as an important barrier to creativity and innovation (Sánchez-Escobedo, Díaz-Casero, HernándezMogollón \& Postigo-Jiménez, 2011). For example, self-employed parents are found to be a key predictor of self-employment (Shapero \& Sokol, 1982). In terms of gender, some authors have emphasised business culture's predominantly masculine nature (Gill \& Ganesh, 2007; Gupta, Goktan \& Gunay, 2014; Ventura \& Quero, 2013). Besides, there still persists traditional roles within families, where men are expected to take over the family business (Verheul et al., 2012). In this sense, societal values implicitly interpret women's entrepreneurship as less desirable and, as a result, society provides less normative support and women themselves perceive the option of creating a firm as less desirable (Díaz-García \& Jiménez-Moreno, 2010). Besides, women tend to be more agreeable towards others and therefore more willing to comply (Maes et al., 2014).

Finally, some research point out the gap between businesswomen's actual abilities and the perception they have of their own skills (Ventura \& Quero, 2013). In this sense, scholars have identified the fact that women choose not to become entrepreneurs because of a perceived lack of control or of self-efficacy (Barnir, Watson \& Hutchins, 2011; Langowitz \& Minniti, 2007; Maes et al., 2014; Wilson et al., 2007). This is true, in particular for activities that are perceived as masculine (Beyer, 1998; Verheul et al., 2012). Moreover, women tend to attribute their achievement of work goals less to their ability and more to hard work (Díaz-García \& Jiménez-Moreno, 2010; Rosenthal, 1995). In the same way, they are less likely to take credit 
for their success and they more often attribute their success to external sources or luck than to their own effort or ability (Verheul et al., 2012).

With this study, we aspire to analyse the moderating effect of gender on TPB dimensions and the effect on entrepreneurial intentions. Considering the aforementioned explanation, we posit the following hypotheses:

Hypothesis 6: Gender moderates the relationship between attitudes towards behaviour and entrepreneurial intentions.

Hypothesis 7: Gender moderates the relationship between perceived behavioural control and entrepreneurial intentions.

Hypothesis 8: Gender moderates the relationship between subjective norms and entrepreneurial intentions.

Hypothesis 9: Gender moderates the relationship between subjective norms and attitudes towards behaviour.

Hypothesis 10: Gender moderates the relationship between subjective norms and perceived behavioural control.

\section{Methodology}

\subsection{Empirical analysis}

An online questionnaire was used for the survey. To test our hypotheses we have used the entrepreneurial intentions questionnaire developed by Liñán et al. (2011) corresponding to a modified version by Liñán and Chen (2009) and Guerrero and Urbano (2014). In order to pretest the survey and ensure that its questions were clear and understandable, we undertook informal interviews with three academics and three students (not included in the final sample) before the actual administration of the final version, who we asked to point out ambiguous, vague or unfamiliar terms. We incorporated their feedback to refine the measurement scales and improve the readability and relevance of the survey instrument. A total of twenty-two questions were part of the final questionnaire which included the measurement of the relevant variables for this research: subjective norms, perceived behavioural control, attitude towards behaviour, entrepreneurial intentions, respondent's gender and university of origin.

This study's target audience consists of university students in the final years of business studies. Our decision for choosing university students to study this issue was taken due to the fact that at such an early stage, their declared entrepreneurial intentions are not influenced by 
their previous experience in the market, but are mostly influenced by their perceptions and attitudes in identifying opportunities. In keeping with this reason, demographic characteristics such as gender seem to be a good indicator for moderating the TPB and the subsequent effect on entrepreneurial intentions. Furthermore, entrepreneurial universities may be seen as an intensive source of knowledge support and entrepreneurial opportunities. Entrepreneurial universities try to provide several university policies and adequate environments where the university community can explore, evaluate and exploit knowledge that could be transformed into new ventures. So, it is for this reason that it makes sense for intentions to be studied in this specific knowledge context (business students at university) (Guerrero \& Urbano, 2014).

The sampling method used was non-probability convenience due to the ease of access to the sample units it presents. This way of obtaining the sample is similar to that used in other studies (Liñán et al., 2011). The sample includes students from one university in Málaga and one in Barcelona. In total, 514 questionnaires were mailed to the respondents and, after deleting the cases with incomplete answers, the sample consisted of 180 emailed individuals (81 males and 99 females), which means a response rate of $35 \%$. Field work was completed on December 2013 and January 2014 and the information obtained was analysed using the statistical software package SPSS version 20.0. and XLSTAT_PLSPM to estimate the proposed model.

\begin{tabular}{|c|l|}
\hline Geographic scope & University Students (Spain) \\
\hline Sampling type & Convenience sample (non-probabilistic sampling) \\
\hline Sample size & 180 business university students \\
\hline Data collection method & Online questionnaire via email \\
\hline Fieldwork date & December (2013) and January (2014) \\
\hline
\end{tabular}

Table 1. Sample characteristics and technical details of the study

\subsubsection{Variable measurement}

The variables considered relevant from the point of view of the objectives of this study were measured using a seven point Likert scale with extremes "Totally disagree" and "Totally agree", with the exception of the interviewee's gender, which was measured using a binary scale (male and female).

In order to avoid acquiescence bias, we used a method similar to the one used in other studies which uses items expressed in a positive sense as well as others on the opposite direction (Liñán et al., 2011). Besides, items measuring each variable were intermingled and randomly 
ordered to minimise response-set bias and halo effect, two common drawbacks of entrepreneurship research instruments (Zahra \& Wiklund, 2002).

Entrepreneurial intentions measurement included six items, two of which were expressed in an opposite sense (Q4, Q6, Q9-rev, Q13, Q17 and Q19-rev). Attitude towards behaviour measurement used five items, two of which presented opposite wording (Q2-rev, Q10, Q12rev, Q15 and Q18). The perceived behavioural control was measured using six items, two of which also presented opposite wording (Q1, Q5-rev, Q7, Q14, Q16-rev and Q20). Finally, subjective norms measurement was carried out using three items (Q3, Q8 and Q11). The entrepreneurial intentions questionnaire (Liñán \& Chen, 2009; Liñán et al., 2011) used is included in Appendix A.

\subsection{Results}

In order to test the proposed hypotheses, the model was evaluated by means of Partial Least Squares (PLS) path modelling, a tool designed to estimate structural equation models and which seeks to minimize the residual variance of the endogenous variables (manifest and latent) (Fornell \& Bookstein, 1982).

PLS path modelling was chosen here for several reasons. First, we are attempting to estimate a complex model that requires the estimation of a large number of parameters with a small sample. Models based on covariance structures (e.g., LISREL) require large sample sizes in order to achieve precise estimations (Kline, 2011). Furthermore, sample size also depends on the complexity of the model, and complex models require larger samples. In this context, an oft-used rule is what is known as the "N:q rule" (Jackson, 2003), according to which between 10 and 20 cases are needed for each estimated parameter. The model proposed here must estimate 45 parameters, which would imply the availability of 450 cases. However, PLS path modelling can be used to estimate complex models even if the sample size is small (Barclay, Thompson \& Higgins, 1995; Tenenhaus, Esposito Vinzi, Chatelin \& Lauro, 2005). The second reason for choosing the PLS approach is that models based on covariance structures assume that the sample follows a multivariate normal distribution (Kline, 2011). On the contrary, this assumption does not have to be fulfilled in PLS path modelling (Chin, Marcolin \& Newsted, 2003). With regards to our data, Mardia's multivariate kurtosis coefficient indicated that the sample did not follow a multivariate normal distribution $(K=91.98 ; p=0.00)$. All this gets more complicated if we consider the moderating role of the interviewee's gender, which would double the number of parameters to estimate. In light of the above, and following other authors' recommendations (Henseler, Ringle \& Sinkovics, 2009), we decided to use PLS path modelling to estimate the proposed model. 
In the estimation of the model, the outer weights were calculated as the covariances between the inner proxy of each latent variable and its indicators (in Mode A, reflective). The inner weights were estimated by means of the path weighting scheme (Lohmöller, 1989). Finally, the standard errors were obtained through bootstrapping using 500 resamples.

A first estimation of the multi-group model suggested, which included every item mentioned in section 3.3, showed that two of them, related to the perceived behavioural control (Q5 and Q16), obtained very low factorial loadings which endanger the internal consistency of scale. That is the reason those items were removed and the new model was estimated again.

Although there is no overall fit index in PLS path modelling, a global criterion of goodness of fit has been proposed by some authors (Esposito Vinzi, Chin, Henseler \& Wang, 2010; Esposito Vinzi, Trinchera \& Amato, 2010). This index, named GoF, has been developed in order to take into account the model's performance in both the measurement and the structural model and thus provide a single measure of its overall prediction performance. The GoF index is bounded between 0 and 1 , and it is descriptive because there is no inference-based threshold to judge the statistical significance of its values. As a rule of thumb, a value of the relative GoF equal to or higher than 0.90 indicates clear support for the model. For the proposed model, the relative GoF reaches a value of 0.78 for men's group and 0.87 for women's group, a reasonable global adjustment. In both groups the outer model obtains a larger global adjustment rate than the inner model does.

With regard to the measurement model, the internal consistency indicators (see Table 2) show that in every case, the values obtained were close to those recommended by the literature or above them (Hair, Black, Babin \& Anderson, 2009), with the exception of the Cronbach's Alpha in the case of subjective norms within men's group. However, it must be taken into account that this internal consistency measurement depends on the number of items in this way favouring scales with a larger number of items. On the other hand, Table 3 shows factor loadings between each manifest variable and its respective latent variable. On it, it can be noticed that all factorial loadings are higher and significantly different from zero, as could be expected. Taking all of this into account, it can be asserted that the scales used in both the men's group as well as in the women's group hold convergent validity. 


\begin{tabular}{|l|c|c|c|c|c|c|}
\cline { 2 - 7 } \multicolumn{1}{c|}{} & \multicolumn{3}{c|}{ Males } & \multicolumn{3}{c|}{ Females } \\
\cline { 2 - 7 } & $\begin{array}{c}\text { Cronbach } \\
\text { Alpha }\end{array}$ & $\begin{array}{c}\text { D.G. } \\
\text { Rho }\end{array}$ & AVE & $\begin{array}{c}\text { Cronbach } \\
\text { Alpha }\end{array}$ & $\begin{array}{c}\text { D.G. } \\
\text { Rho }\end{array}$ & AVE \\
\hline Subjective norms (SN) & 0.623 & 0.796 & 0.569 & 0.841 & 0.904 & 0.759 \\
\hline $\begin{array}{l}\text { Perceived behavioural control } \\
\text { (PBC) }\end{array}$ & 0.743 & 0.835 & 0.559 & 0.768 & 0.849 & 0.587 \\
\hline $\begin{array}{l}\text { Attitude towards the behaviour } \\
\text { (ATT) }\end{array}$ & 0.845 & 0.890 & 0.620 & 0.895 & 0.922 & 0.704 \\
\hline $\begin{array}{l}\text { Entrepreneurial intentions } \\
\text { (EIN) }\end{array}$ & 0.913 & 0.933 & 0.698 & 0.925 & 0.942 & 0.731 \\
\hline
\end{tabular}

Table 2. Internal consistency for used scales

\begin{tabular}{|c|c|c|c|c|c|c|c|c|}
\hline & \multicolumn{4}{|c|}{ Males } & \multicolumn{4}{|c|}{ Females } \\
\hline & SN & PBC & ATT & EIN & SN & PBC & ATT & EIN \\
\hline Q3 & 0.716 & & & & 0.898 & & & \\
\hline Q8 & 0.654 & & & & 0.841 & & & \\
\hline Q11 & 0.876 & & & & 0.875 & & & \\
\hline Q1 & & 0.753 & & & & 0.763 & & \\
\hline Q7 & & 0.756 & & & & 0.806 & & \\
\hline Q14 & & 0.807 & & & & 0.830 & & \\
\hline Q20 & & 0.669 & & & & 0.653 & & \\
\hline Q2 & & & 0.773 & & & & 0.784 & \\
\hline Q10 & & & 0.812 & & & & 0.836 & \\
\hline Q12 & & & 0.829 & & & & 0.873 & \\
\hline Q15 & & & 0.873 & & & & 0.859 & \\
\hline Q18 & & & 0.626 & & & & 0.841 & \\
\hline Q4 & & & & 0.787 & & & & 0.818 \\
\hline Q6 & & & & 0.806 & & & & 0.804 \\
\hline Q9 & & & & 0.794 & & & & 0.766 \\
\hline Q13 & & & & 0.855 & & & & 0.901 \\
\hline Q17 & & & & 0.880 & & & & 0.917 \\
\hline Q19 & & & & 0.887 & & & & 0.912 \\
\hline
\end{tabular}

Table 3. Loadings between manifest and latent variables

With respect to discriminant validity, Tables 4 and 5 show the correlations between the latent constructs, as well as the AVE for each one of them. According to Fornell and Larcker (1981), discriminant validity is present if the squared correlation between each pair of latent constructs is lower than the AVE. The results show that this condition is fulfilled in both groups, confirming in this way the existence of discriminant validity between the latent variables used in this study. 


\begin{tabular}{|c|c|c|c|c|c|}
\cline { 2 - 6 } \multicolumn{1}{c|}{} & SN & PBC & ATT & EIN & AVE \\
\hline SN & 1 & 0.034 & 0.170 & 0.062 & 0.569 \\
\hline PBC & 0.034 & 1 & 0.196 & 0.367 & 0.559 \\
\hline ATT & 0.170 & 0.196 & 1 & 0.633 & 0.620 \\
\hline EIN & 0.062 & 0.367 & 0.633 & 1 & 0.698 \\
\hline AVE & 0.569 & 0.559 & 0.620 & 0.698 & 0 \\
\hline
\end{tabular}

Table 4. Discriminant validity (males)

\begin{tabular}{|c|c|c|c|c|c|}
\cline { 2 - 6 } \multicolumn{1}{c|}{} & SN & PBC & ATT & EIN & AVE \\
\hline SN & 1 & 0.199 & 0.154 & 0.138 & 0.759 \\
\hline PBC & 0.199 & 1 & 0.407 & 0.531 & 0.587 \\
\hline ATT & 0.154 & 0.407 & 1 & 0.709 & 0.704 \\
\hline EIN & 0.138 & 0.531 & 0.709 & 1 & 0.731 \\
\hline AVE & 0.759 & 0.587 & 0.704 & 0.731 & 0 \\
\hline
\end{tabular}

Table 5. Discriminant validity (females)

Inner model's coefficients are shown in Figure 1 for both men and women. A first conclusion is that the model gets to explain more than $72 \%$ of the entrepreneurial intentions variance in the men's group, while this percentage is even higher in the women's group (77\%). Both the attitude towards behaviour and the perceived behavioural control are significant antecedents of entrepreneurial intentions, while subjective norms do not have a significant influence. This conclusion is as valid for the men's group as for the women's. Therefore, $\mathrm{H} 1$ and $\mathrm{H} 2$ are empirically supported, but $\mathrm{H} 3$ and $\mathrm{H} 8$ should be rejected. Furthermore, a comparison between both groups' coefficients for the mentioned relations clearly shows that interviewees' gender does not work as a moderating variable, as significant differences between them cannot be found $(p=0.895[$ PBC $\rightarrow$ EIN]; $p=0.653$ [ATT $\rightarrow$ EIN]). Therefore, we reject $\mathrm{H} 6$ and $\mathrm{H} 7$.

Secondly, the subjective norms' influence on attitude towards behaviour is significantly different from zero, in both the men's and the women's group ( $\mathrm{H} 4$ is empirically supported). This time, subjective norms get to explain $17 \%$ of attitude towards behaviour variability in the men's group and $15.4 \%$ in the women's group. A comparison of coefficients between both groups shows that there are not any differences between them either, which suggests that interviewees' gender does not play a moderating role in this relation neither $(p=0.904[S N \rightarrow$ ATT]). Therefore, H9 should be rejected.

Finally, the relation between subjective norms and perceived control is not significant within the men's group while in the women's group it is significantly different from zero ( $\beta S N \rightarrow$ PBC 
$[$ men] $=0.185 ; \mathrm{p}>0.05 ; \beta S N \rightarrow \mathrm{PBC}[$ women $]=0.446 ; \mathrm{p}=0.00)$. This result makes clear that interviewees' gender plays a moderating role in this relation. In a more specific way, support on the part of the most important reference groups positively influences the perception of behavioural control in the women's case, whereas in the men's case this relation is not significant. As a consequence, perceived behavioural control in the women's group explained variance is $19.9 \%$, while in the men's group it is only $3.4 \%$ ( $p>0.05)$. Therefore, $\mathrm{H} 10$ is empirically supported but $\mathrm{H} 5$ should be rejected.

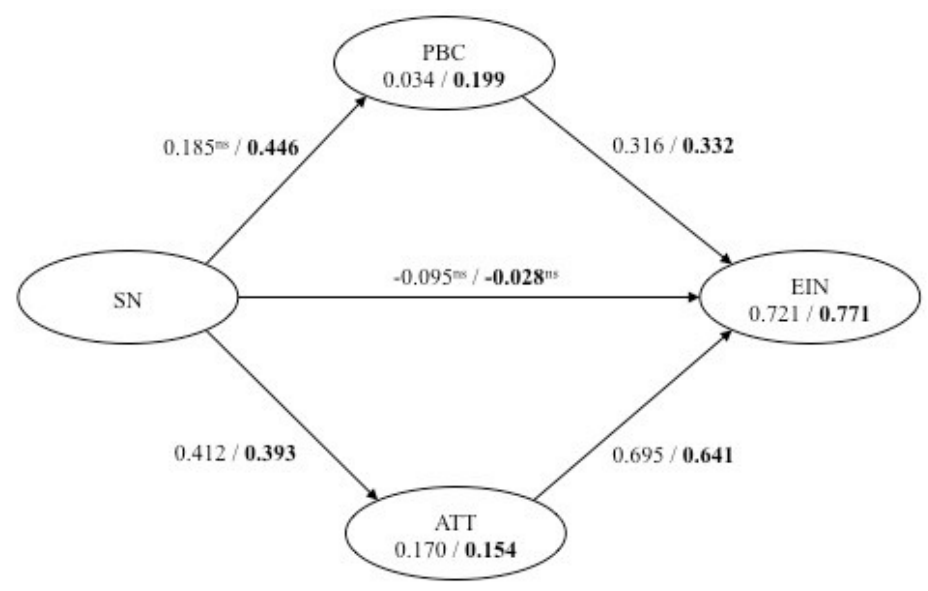

Figure 1. Inner model coefficients (males and females [bold])

\section{Concluding remarks}

\subsection{Discussion}

There is general agreement in previous research (drawing on the TPB) that attitudes towards entrepreneurship are determining factors on entrepreneurial intentions and that gender also seems to play a key role (Díaz-García \& Jiménez-Moreno, 2010).

This study adopts the TPB model proposed by Ajzen (1991) moderated by gender variable to investigate how subjective norms, attitudes and perceived behavioural control influence Spanish university students' entrepreneurial intentions. The empirical results show that students' attitudes towards creating a new firm and perceived behavioural control indeed exert positive influences on entrepreneurial intentions. These results are consistent with those yielded by previous studies and jointly explain $72 \%$ and $77 \%$ of the variation in intentions in men and woman respectively, which is more than the typical in previous studies. On the other 
hand, subjective norms, values transmitted by "reference people", do not seem to influence entrepreneurial intentions in a different way in our case. In any case, it is found to exert an indirect effect on entrepreneurial intentions, influencing both genders by means of attitudes, and also, only in the women's case, perceived behavioural control. Besides and in relation to subjective norms' influence, it is found in the female students' case that these norms get to explain $19 \%$ of variability towards perceived behavioural control. A possible explanation for these results can be related to the larger influence reference groups have on women in comparison with men. In fact, examining subjective norms from a gender perspective, the literature on gender differences and gender roles suggests that women have higher affiliation needs and are thus more concerned to please others and more likely to conform to majority opinions (Morris, Venkatesh \& Ackerman, 2005). Moreover, apart from this difference found on subjective norms' influence on women and perceived behavioural control, students' gender is not found to exert any other moderating effect when explaining entrepreneurial intentions. These results could be indicating that old stereotypes that portray entrepreneurial and selfemployment career choice intentions as a male-oriented domain may be disappearing, except for the larger influence of the perceived social pressure women feel.

To sum up, our research findings make some theoretical contributions to the literature on entrepreneurial intentions.

\subsection{Implications}

The findings of this study have several implications. Since the decision to become an entrepreneur may be plausibly considered as voluntary and conscious, it seems reasonable to analyse how that decision is taken. The results will allow the designing of more effective education initiatives (Liñán et al., 2011) and policies (Liñán \& Chen, 2009).

According to Ribeiro (2004) education and training have a positive impact on the accumulation of knowledge that is needed for entrepreneurship. Education can influence young people's attitudes and aspirations towards entrepreneurship, Besides, some studies find that participation in programmes that motivate business creation substantially increases the perception of the viability of a business start-up (Sánchez-Escobedo et al., 2011).

Our research confirms that in women, subjective norms is a previous element helping to determine perceived behavioural control. In that sense, it can be important for improving economic growth to encourage that group of individuals that are under represented in the entrepreneurial population by the promotion of an entrepreneurially friendly culture (Liñán \& Chen, 2009; Verheul et al., 2012). 


\subsection{Limitations and further research}

This study contains some limitations that offer opportunities for further research. First, our focus has been on intentions rather than on actual start-up decisions, and the use of intentions as a dependent variable is affected by the difference between what is anticipated or desirable and what actually entails real behaviour. Another limitation comes from the fact that other control variables such as self-efficacy, professional experience, educational level, role models, etc. have not been used.

As future research lines, it would be desirable to conduct a comparative study among several geographical areas within the same country or even a number of countries. Also, if there exist suitable scales in order to be able to analyse the subjective norms (friends, etc.) with less influence on people with a strong locus of control than on those with strong action, the measurement of the respondents' locus of control could be included within the research (Ajzen, 2002).

\section{References}

AJZEN, I. (1991). The Theory of Planned Behaviour. Organizational behaviour and human decision processes, 50: 179-211. http://dx.doi.org/10.1016/0749-5978(91)90020-T

AJZEN, I. (2001). Attitudes. Annual Review of Psychology, 52 (1): 27-58. http://dx.doi.org/10.1146/annurev.psych.52.1.27

AJZEN, I. (2002). Perceived behavioural control, self-efficacy, locus of control, and the theory of planned behaviour. Journal of Applied Social Psychology, 32(4): 665-683. http://dx.doi.org/10.1111/j.1559-1816.2002.tb00236.x

AJZEN, I. (2011). The theory of planned behavior: Reactions and reflections. Psychology \& Health, 26(9): 1113-1127. http://dx.doi.org/10.1080/08870446.2011.613995

AJZEN, I.; FISHBEIN, M. (1980). Understanding attitudes and predicting social behavior. Englewood-Cliffs, NJ: Prentice-Hall.

ARMITAGE, C.J.; CONNER, M. (2001). Efficacy of the Theory of Planned Behaviour: A metaanalytic review. British Journal of Social Psychology, 40: 4714-4799. http://dx.doi.org/10.1348/014466601164939

AUTIO, E. (2011). High-aspiration entrepreneurship. In M. Minniti (Ed.), The dynamics of entrepreneurship (pp. 181-208). Oxford: Oxford University Press. 
AUTIO, E.; ACS, Z. (2010). Intellectual property protection and the formation of entrepreneurial growth aspirations. Strategic Entrepreneurship Journal, 4, 234-251.

http://dx.doi.org/10.1002/sej.93

AUTIO, E.; KEELEY, R.H.; KLOFSTEN, M.G.; PARKER, G.C.; HAY, M. (2001). Entrepreneurial intent among students in Scandinavia and in the USA. Enterprise and Innovation Management Studies, 2(2): 145-160. http://dx.doi.org/10.1080/14632440110094632

BARCLAY, D.; THOMPSON, R.; HIGGINS, C. (1995). The Partial Least Squares (PLS) approach to causal modeling: Personal computer adoption and use an illustration. Technology Studies, 2(2): 285-309.

BARNIR, A.; WATSON, W.E.; HUTCHINS, H.M. (2011). Mediation and moderated mediation in the relationship among role models, self-efficacy, entrepreneurial career intention and gender. Journal of Applied Social Psychology, 41(2): 270-297. http://dx.doi.org/10.1111/j.15591816.2010.00713.x

BEYER, S. (1998). Gender differences in self-perception and negative recall biases. Sex Roles, 38(1-2): 103-133. http://dx.doi.org/10.1023/A:1018768729602

BIRD, B. (1988). Implementing entrepreneurial ideas: The case for intention. Academy of Management Review, 13: 442-453.

BLANCHFLOWER, D.G.; OSWALD, A.J. (1998). What Makes an Entrepreneur?. Journal of labour economics, 16(1): 26-60.

BOSMA, N.; JONES, K.; AUTIO, E.; LEVIE, J. (2008). Global entrepreneurship monitor (2007). Executive Report. USA: London Business School and Babson College.

BRENNER, O.C.; PRINGLE, C.D.; GREENHAUS, J.H. (1991). Perceived fulfilment of organizational employment versus entrepreneurship: Work values and career intentions of business college graduates. Journal of Small Business Management, 29(3): 62-74.

BRUNI, A.; GHERADI, S.; POGGIO, B. (2004). Entrepreneur-mentality, gender and the study of women entrepreneurs. Journal of Organizational Change Management, 17: 256-268. http://dx.doi.org/10.1108/09534810410538315

BRUSH, C.G. (1992). Research on women business owners: past trends, a new perspective and future directions. Entrepreneurship Theory and Practice, 16(4): 5-30.

CARR, J.C.; SEQUEIRA, J.M. (2007). Prior family business exposure as intergenerational influence and entrepreneurial intent: A theory of planned behavior approach. Journal of Business Research, 60(10): 1090-1098. http://dx.doi.org/10.1016/j.jbusres.2006.12.016 
CHIN, W.W.; MARCOLIN, B.L.; NEWSTED, P.N. (2003). A partial least, squares latent variable modeling approach for measuring interaction effects: Results from a Montecarlo simulation study and an electronic-mail emotion/adoption study. Information Systems Research, 14(2): 189-217. http://dx.doi.org/10.1287/isre.14.2.189.16018

DE CLERCQ, D.; HONIG, D.; MARTIN, B. (2011). The roles of learning orientation and passion for work in the formation of entrepreneurial intention. International Small Business Journal, 31(6): 652-676. http://dx.doi.org/10.1177/0266242611432360

DELMAR, F.; DAVIDSSON, P. (2000). Where do they come from? Prevalence and characteristics of nascent entrepreneurs. Entrepreneurship \& Regional Development, 12: 1-23. http://dx.doi.org/10.1080/089856200283063

DÍAZ-GARCÍA, M.C.; JIMÉNEZ-MORENO, J. (2010). Entrepreneurial intention: The role of gender. International Entrepreneurship and Management Journal, 6(3): 261-283. http://dx.doi.org/10.1007/s11365-008-0103-2

ESPOSITO VINZI, V.; CHIN, W.W.; HENSELER, J.; WANG, H. (2010). Handbook of Partial Least Squares. Concepts, Methods and Applications. Berlin: Springer Handbooks of Computational Statistics. http://dx.doi.org/10.1007/978-3-540-32827-8

ESPOSITO VINZI, V.; TRINCHERA, L.; AMATO, S. (2010). PLS path modeling: from foundations to recent developments and open issues for model assessment and improvement. In $\mathrm{V}$. Esposito Vinzi et al. (Ed.), Handbook of Partial Least Squares (pp. 47-82). ED: Berlin.

ESTRIN, S.; KOROSTELEVA, J.; MICKIEWICZ, T. (2013). Which institutions encourage entrepreneurial growth aspirations?. Journal of Business Venturing, 28: 564-580. http://dx.doi.org/10.1016/j.jbusvent.2012.05.001

FITZSIMMONS, J.R.; DOUGLAS, E.J. (2011). Interaction between feasibility and desirability in the formation of entrepreneurial intentions. Journal of Business Venturing, 26: 431-440.

http://dx.doi.org/10.1016/j.jbusvent.2010.01.001

FORNELL, C.; BOOKSTEIN, F.L. (1982). Two structural models: LISREL and PLS applied to consumer exit-voice theory. Journal of Marketing Research, 19: 440-452. http://dx.doi.org/10.2307/3151718

FORNELL, C.; LARCKER, D.F. (1981). Evaluating structural equation models with unobservable variables and measurement error. Journal of Marketing Research, 18: 39-50.

http://dx.doi.org/10.2307/3151312

GARTNER, W.; LIAO, J. (2012). The effects of perceptions of risk, environmental uncertainty, and growth aspirations on new venture creation success. Small Business Economics, 39: 703-712. http://dx.doi.org/10.1007/s11187-011-9356-1 
GILL, R.; GANESH, S. (2007). Enpowerment, constraint, and the entrepreneurial self: a study of white women entrepreneurs. Journal of Applied Communication Research, 35(3): 268-293. http://dx.doi.org/10.1080/00909880701434265

GUERRERO, M.; URBANO, D. (2014). Academics' start-up intentions and knowledge filters: an individual perspective of the knowledge spill over theory of entrepreneurship. Small Business Economics, 43(1): 57-74. http://dx.doi.org/10.1007/s11187-013-9526-4

GUPTA, V.K.; GOKTAN, A.B.; GUNAY, G. (2014). Gender differences in evaluation of new business opportunity: A stereotype threat perspective. Journal of Business Venturing, 29: 273-288. http://dx.doi.org/10.1016/j.jbusvent.2013.02.002

HAIR, J.F.; BLACK, W.C.; BABIN, B.J.; ANDERSON, R.E. (2009). Multivariate data analysis. Upper Saddle River, NJ: Prentice Hall.

HENSELER, J.; RINGLE, C.M.; SINKOVICS, R.R. (2009). The use of partial least squares path modeling in international marketing. Advances in International Marketing, 20: 277-319. http://dx.doi.org/10.1108/S1474-7979(2009)0000020014

HESSELS, J.; VAN GELDEREN, M.; THURIK, R. (2008a). Drivers of entrepreneurial aspirations at the country level: the role of start-up motivations and social security. International Entrepreneurship and Management Journal, 4(4): 401-417. http://dx.doi.org/10.1007/s11365-0080083-2

HESSELS, J.; VAN GELDEREN, M.; THURIK, R. (2008b). Entrepreneurial aspirations, motivations, and their drivers. Small Business Economics, 31(3): 323-339.

http://dx.doi.org/10.1007/s11187-008-9134-x

HMIELESKI, K.M.; CORBETT, A.C. (2006). Proclivity for improvisation as a predictor of entrepreneurial intentions. Journal of Small Business Management, 44(1): 45-63.

http://dx.doi.org/10.1111/j.1540-627X.2006.00153.x

JACKSON, D.L. (2003). Revisiting sample size and number of parameter estimates: Some support for the N:q hypothesis. Structural Equation Modeling, 10: 128-141.

http://dx.doi.org/10.1207/S15328007SEM1001_6

KAUTONEN, T.; GELDEREN, M.V.; TORNIKOSKI, E.T. (2013). Predicting entrepreneurial behaviour: A test of the theory of planned behaviour. Applied Economics, 45: 697-707. http://dx.doi.org/10.1080/00036846.2011.610750

KAUTONEN, T.; PALMROOS, J.; VAINIO, P. (2009). Involuntary self-employment in Finland: A bleak future?. International Journal of Public Policy, 4(6): 533-548. 
KIRBY, D.A.; GUERRERO, M.; URBANO, D. (2011). The theoretical and empirical side of entrepreneurial universities: An institutional approach. Canadian Journal of Administrative Science, 28(3): 302-316. http://dx.doi.org/10.1002/cjas.220

KIRK, J.; BELOVICS, R. (2006). Counselling would-be entrepreneurs. Journal of Employment Counselling, 43(2): 50-62. http://dx.doi.org/10.1002/j.2161-1920.2006.tb00006.x

KLINE, R.B. (2011). Principles and practice of structural equation modeling. New York: The Guilford Press.

KOLVEREID, L. (1996). Prediction of employment status choice intentions. Entrepreneurship Theory and Practice, 21(1): 47-57.

KOURILSKY, M.; WALSTAD, M. (1998). Entrepreneurship and female youth: Knowledge, attitudes, gender differences and educational practices. Journal of Business Venturing, 13: 77-88. http://dx.doi.org/10.1016/S0883-9026(97)00032-3

KRAUS, S.J. (1995). Attitudes and the prediction of behaviour: A meta-analysis of the empirical literature. Personality and Social Psychology Bulletin, 21(1): 58-75.

http://dx.doi.org/10.1177/0146167295211007

KRUEGER, N.F. ; BRAZEAL, D.V. (1994). Entrepreneurial Potential and Potential Entrepreneurs. Entrepreneurship Theory and Practice, 18(3): 91-104.

KRUEGER, N.F.; CARSRUD, A.L. (1993). Entrepreneurial intentions: Applying the theory of planned behaviour. Entrepreneurship and Regional Development, 5: 315-330.

http://dx.doi.org/10.1080/08985629300000020

KRUEGER, N.F.; REILLY, M.D.; CARSRUD, A.L. (2000). Competing models of entrepreneurial intentions. Journal of Business Venturing, 15(5-6): 411-432.

http://dx.doi.org/10.1016/S0883-9026(98)00033-0

LANGOWITZ, N.; MINNITI, M. (2007). The entrepreneurial propensity of women. Entrepreneurship Theory \& Practice, 31(3): 341-364.

http://dx.doi.org/10.1111/j.1540-6520.2007.00177.x

LENT, R.W.; BROWN, S.D.; HACKETT, G. (1994). Toward a unifying social cognitive theory of career and academic interest, choice, and performance. Journal of Vocational Behavior, 45 : 79-122. http://dx.doi.org/10.1006/jvbe.1994.1027

LERNER, M.; MALACH-PINES, A. (2010). Gender and culture in family business: A ten-nation study. International Journal of Cross Cultural Management, 11(2): 113-131. 
LEVESQUE, M.; MINNITI, M. (2006). The effect of aging on entrepreneurial behaviour. Journal of Business Venturing, 21(2): 177-194. http://dx.doi.org/10.1016/j.jbusvent.2005.04.003

LIÑÁN, F. (2004). Intention-based models of entrepreneurship education. Piccola Impresa / Small Business, 2004(3): 11-35.

LIÑÁN, F.; CHEN, Y.W. (2009). Development and cross-cultural application of a specific instrument to measure entrepreneurial intentions. Entrepreneurship Theory and Practice, 33(3): 593-617. http://dx.doi.org/10.1111/j.1540-6520.2009.00318.x

LIÑÁN, F.; SANTOS, F.J. (2007). Does social capital affect entrepreneurial intentions?. International Advances in Economic Research, 13(4): 443-453. http://dx.doi.org/10.1007/s11294007-9109-8

LIÑÁN, F.; URBANO, D.; GUERRERO, M. (2011). Regional variations in entrepreneurial cognitions: Start-up intentions of university students in Spain. Entrepreneurship \& Regional Development, 23(3-4): 187-215. http://dx.doi.org/10.1080/08985620903233929

LOHMÖLLER, J.B. (1989). Latent Variable Path Modeling with Partial Least Squares. Heide, Germany: Physica-Verlag. http://dx.doi.org/10.1007/978-3-642-52512-4

MAES, J.; LEROY, H.; SELS, L. (2014). Gender differences in entrepreneurial intentions: A TPB multi-group analysis at factor and indicator level. In press.

http://dx.doi.org/10.1016/j.emj.2014.01.001

MATTHEWS, C.H.; MOSER, S.B. (1995). Family background and gender: Implications for interest in small firm ownership. Entrepreneurship and Regional Development, 7(4): 365-377. http://dx.doi.org/10.1080/089856295000000023

MAZZAROL, T.T.; VOLERY, N.; DOSS, M.; THEIN, V. (1999). Factors influencing small business start-ups. A comparison with previous research. International Journal of Entrepreneurial Behaviour and Research, 5(2): 48-63. http://dx.doi.org/10.1108/13552559910274499

MINNITI, M.; NARDONE, C. (2007). Being in someone else's shoes: Gender and nascent entrepreneurship. Small business economics journal, 28(2-3): 223-239.

MITCHELL, R.K.; BUSENITZ, L.W.; BIRD, B.; GAGLIO, C.M.; MCMULLEN, J.S.; MORSE, E.A. (2007). The central question in entrepreneurial cognition research. Entrepreneurship Theory and Practice, 31(1): 1-27. http://dx.doi.org/10.1111/j.1540-6520.2007.00161.x

MORIANO, J.A.; GORGIEVSKI, M.; LAGUNA, M.; STEPHAN, U.; ZARAFSHANI, K. (2012). A cross-cultural approach to understanding entrepreneurial intention. Journal of career development, 39(2): 162-185. http://dx.doi.org/10.1177/0894845310384481 
MORRIS, M.G.; VENKATESH, V.; ACKERMAN, P.L. (2005). Gender and age differences in employee decisions about new technology: An extension to the Theory of Planned Behaviour. IEEE Transactions on engineering management, 52:69-84.

http://dx.doi.org/10.1109/TEM.2004.839967

PINES, A.M.; LERNER, M.; SCHWARTZ, D. (2010). Gender differences in entrepreneurship. Equality, diversity and inclusion in times of global crisis. Equality, Diversity and Inclusion: An International Journal, 29(2): 186-198.

RIBEIRO, D. (2004). Análisis aproximativo de las variables influyentes en el empresario and emprendedor de éxito en el contexto teórico internacional. In S. Roig D, V.R. Ribeiro, A. Torcal \& E. Cerver (Eds.), El emprendedor innovador y la creación de empresas de $I+D+I$ (pp. 121-130). Valencia: Universitat de València.

RODRÍGUEZ, M.J.; SANTOS, F.J. (2008). La actividad emprendedora de las mujeres y el proceso de creación de empresas. Información Comercial Española, 841: 117-132.

ROSENTHAL, P. (1995). Gender differences in managers' attributions for successful work performance. Women in Management Review, 10(6): 16-31.

http://dx.doi.org/10.1108/09649429510096006

SÁNCHEZ-ESCOBEDO, M.C.; DÍAZ-CASERO, J.C.; HERNÁNDEZ-MOGOLLÓN, R.; POSTIGOJIMÉNEZ, M.V. (2011). Perceptions and attitudes towards entrepreneurship. An analysis of gender among university students. International Entrepreneurship and Management Journal, 7: 443-463. http://dx.doi.org/10.1007/s11365-011-0200-5

SCHERER, R.F.; ADAMS, J.S.; CARLEY, S.S.; WIEBE, F.A. (1989). Role Model Performance Effects on the Development of Entrepreneurial Career Preference. Entrepreneurship: Theory and Practice, 13(3): 53-71.

SHANE, S. (1992). Why do some societies invent more than others?. Journal of Business Venturing, 7(1): 29-46. http://dx.doi.org/10.1016/0883-9026(92)90033-N

SHAPERO, A.; SOKOL, L. (1982). The social dimensions of entrepreneurship. In C. A. Kent, D.L. Sexton \& K.H. Vesper (Eds.), Encyclopaedia of entrepreneurship (pp. 288-307). Englewood Cliffs: Prentice Hall.

SHOOK, C.L.; PRIEM, R.L.; MCGEE, J.E. (2003). Venture creation and the enterprising individual: A review and synthesis. Journal of Management, 29(3): 379-399.

http://dx.doi.org/10.1016/S0149-2063(03)00016-3

TENENHAUS, M.; ESPOSITO VINZI, V.; CHATELIN, Y.M.; LAURO, C. (2005). PLS path modeling. Computational Statistics and Data Analysis, 48(1): 159-205. 
THOMPSON, E.R. (2009). Individual Entrepreneurial Intent: Construct Clarification and Development of an Internationally Reliable Metric. Entrepreneurship. Theory and Practice, 33(3): 669-694. http://dx.doi.org/10.1111/j.1540-6520.2009.00321.x

TKACHEV, A.; KOLVEREID, L. (1999). Self-employment intentions among Russian students. Entrepreneurship and Regional Development, 11(3): 269-280.

http://dx.doi.org/10.1080/089856299283209

TOMINC, P.; REBERNIK, M. (2007). Growth Aspirations and Cultural Support for Entrepreneurship: A Comparison of Post-Socialist Countries. Small Business Economics, 28: 239-255. http://dx.doi.org/10.1007/s11187-006-9018-x

URIBE, J.; DE PABLO, J.; BONILLA, J.J. (2013). El desarrollo local y empresarial: La formación como factor básico para orientar al emprendedor. Intangible Capital, 9(3): 644-677.

VAN GELDEREN, M.; BRAND, M.; VAN PRAAG, M.; BODEWES, W.; POUTSMA, E.; VAN GILS, A. (2008). Explaining entrepreneurial intentions by means of the Theory of Planned Behaviour. Career Development International, 13: 538-559. http://dx.doi.org/10.1108/13620430810901688

VECIANA, J.M.; APONTE, M.S.; URBANO, D. (2005). University Students' Attitudes Towards. Entrepreneurship: A Two Countries Comparison. International Entrepreneurship and Management Journal, 1: 165-182. http://dx.doi.org/10.1007/s11365-005-1127-5

VENTURA, R.; QUERO, M.J. (2013). Factores explicativos de la intención de emprender en la mujer. Aspectos diferenciales en la población universitaria según la variable género. Cuadernos de Gestión, 13(1): 127-149. http://dx.doi.org/10.5295/cdg.100271rv

VERHEUL, I.; THURIK, R.; GRILO, I.; VAN DER ZWAN, P. (2012). Explaining preferences and actual involvement in self-employment: Gender and the entrepreneurial personality. Journal of Economic Psychology, 33: 325-341. http://dx.doi.org/10.1016/j.joep.2011.02.009

WILSON, F.; KICKUL, J.; MARLINO, D. (2007). Gender, entrepreneurial self-efficacy, and entrepreneurial career intentions: Implications for entrepreneurship education. Entrepreneurship Theory and Practice, 30(1): 387-406.

http://dx.doi.org/10.1111/j.1540-6520.2007.00179.x

ZAHRA, S.A.; WIKLUND, J. (2002). Top management team characteristics and entrepreneurial resource recombinations among new ventures. Mimeo, Jonkoping International Business School, Jonkoping, Sweden. Available online at: http://www.sbaer.uca.edu/research/icsb/2000/pdf/101

ZHAO, H.; HILLS, G.E.; SIEBERT, S.E. (2005). The mediating role of self-efficacy in the development of entrepreneurial intentions. Journal of Applied Psychology, 90(6): 1265-1272. http://dx.doi.org/10.1037/0021-9010.90.6.1265 


\section{Appendix A: Entrepreneurial Intentions Questionnaire}

(Liñán and Chen, 2009; Liñán et al., 2011)

\section{Entrepreneurial intentions (EIN):}

Q4. I am ready to do anything to be an entrepreneur.

Q6. I will make every effort to start and run my own business.

Q9. I have serious doubts about ever starting my own business.

Q13. I am determined to create a business venture in the future.

Q17. My professional goal is to be an entrepreneur.

Q19. I have a very low intention of ever starting a business.

\section{Attitude towards behaviour (ATT):}

Q2. A career as an entrepreneur is totally unattractive to me.

Q15. Being an entrepreneur would give me great satisfaction.

Q10. If I had the opportunity and resources, I would love to start a business.

Q12. Amongst various options, I would rather be anything but an entrepreneur.

Q18. Being an entrepreneur implies more advantages than disadvantages to me.

\section{Perceived behavioural control (PBC):}

Q7. I am able to control the creation process of a new business.

Q1. Starting a firm and keeping it viable would be easy for me.

Q5. I believe I would be completely unable to start a business.

Q14. If I tried to start a business, I would have a high chance of being successful.

Q16. It would be very difficult for me to develop a business idea.

Q20. I know all about the practical details needed to start a business. 


\section{Subjective norm (SN):}

Q3. My friends would approve of my decision to start a business.

Q8. My immediate family would approve of my decision to start a business.

Q11. My colleagues would approve of my decision to start a business.

Intangible Capital, 2015 (www.intangiblecapital.org)

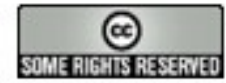

Article's contents are provided on a Attribution-Non Commercial 3.0 Creative commons license. Readers are allowed to copy, distribute and communicate article's contents, provided the author's and Intangible Capital's names are included. It must not be used for commercial purposes. To see the complete license contents, please visit http://creativecommons.org/licenses/by-nc/3.0/. 